\title{
Strengthening the Roles of Judicial Commission
}

\author{
Ujang Bahar* \\ DOI: https://doi.org/10.22304/pjih.v5n2.a10
}

Submitted: June 21, 2018 | Accepted: August 31, 2018

\begin{abstract}
This paper discusses the role of judicial commission (JC) in some states of the world based on their respective constitutions. Especially Indonesia, the role can be strengthened by amending the 1945 Constitution. JC is an independent institution that functions to strengthen a credible, efficient, and effective judiciary, which is trusted by the people. As a supporting institution focus JC differences in the world. There are focuses attention on technical policy, making and budgeting of the judiciary, while others emphasize to the problems career, recruitment, discipline, ethics and behavior of judges. Therefore, each country should increase the role of $\mathrm{JC}$ institution by taking and adding positive things in the implementation. In addition, since the foundation of JC is related closely to the performance of judges, it is time for each state to give full authority to the JC to conduct audit of judge's decision (verdict), to supervise honor, nobility, ethics, and dignity of judges
\end{abstract}

Keywords: conduct and ethics, judges, supervision.

\section{Penguatan Peran Komisi Yudisial}

\begin{abstract}
Tulisan ini membahas tentang peran Komisi Yudisial (KY) masing-masing negara di dunia sesuai yang tercantum dalam konstitusinya. Khusus untuk indonesia peran tersebut dapat diperkuat dengan mengamandemen UUD 1945. KY merupakan satu lembaga negara independen dengan tugas dan wewenang mendukung terwujudnya lembaga peradilan yang kredibel, efisien dan efektif dan dipercaya masyarakat. Sebagai lembaga penunjang terdapat perbedaan fokus perhatian KY di antara negara-negara di dunia. Ada yang menitik beratkan perhatian pada pembuatan kebijakan teknis dan penganggaran peradilan, sementara yang lain menitik beratkan kepada masalah karier, rekrutmen, disiplin, etika dan tingkah laku hakim. Oleh karena itu sudah seharusnya masing-masing negara meningkatkan peran lembaga KY nya dengan mengambil dan menambahkan hal positif pada praktik pada negara lain. Lain dari pada itu karena eksistensi $K Y$ sangat bersentuhan dengan kinerja hakim, maka sudah saatnya masing-masing negara memberikan kewenangan kepada KY untuk melakukan audit terhadap vonis (putusan hakim) dalam rangka melakukan pengawasan menjaga kehormatan, keluhuran, etika, dan martabat hakim.
\end{abstract}

Kata kunci: hakim, pengawasan, perilaku dan etika.

PADJADJARAN Journal of Law Volume 5 Number 2 Year 2018 [ISSN 2460-1543] [e-ISSN 2442-9325]

Senior Lecturer at Faculty of Law, Djuanda University Bogor, lecturer at state College of Accountancy, Ministry of Finance in Bintaro, Jakarta, ujang_bahar@yahoo.co.id, S.H. (Universitas Islam Riau), M.Si. (Universitas Hasunuddin), Dr. (Universitas Padjadjaran). 


\section{A. Introduction}

According to Thohari, every state has its respective background of the establishment of JC. There are, at least, five reason: ${ }^{1}$

(1) the lack of an intensive monitoring power, because the monitoring is done internally;

(2) the absence of institution that mediates the government (executive power) and judicial power;

(3) the judicial power is not considered to have sufficient efficiency and effectiveness in carrying out its duties if it is still preoccupied by non-legal technical issue;

(4) the lack of consistency of judicial decisions, because every decision obtains less appraisal and strict supervision from a specialized institution; and

(5) the pattern of judge recruitment has been considered too biased because of political problems since the institution that proposes and recruits is a political institution.

One of the five reasons that mentioned above is background JC establishment in a state. The common reasons are to raise public trust and to develop and to make a credible and efficient justice. In the European states, the background of the birth of JC is inspired by the wave of democracy in Eastern Europe that demands the judicial process to be fair. The original idea of founding is to be a connector government interests and the interests of justice. ${ }^{2}$ In that context, the main role of $\mathrm{JC}$ is to ensure the justice system, proposed the candidate judges were professional, providing quality education to the judge, to test competence of the judge, upholding the code of etic of judge, developing the public network, and takes over the judicial management functions responsibility from government.

It is formulated with a variety of continued authority, namely regarding disciplinary action, careers, selection, training, and general policy on the parts of public services, such as facilities exist in the judicial, budget, official residence, and improved technology. ${ }^{3}$ In the Indonesian context, the background of the JC formed need for independence as doctrine supremacy of law. Besides impact of legal reforms through institutional reform which unites all judicial authorities including organizational, administrative, personnel and budgeting in the Supreme Court (SC). ${ }^{4}$ In addition, there are fears to SC not self-sufficient and not performable authority.

Ahsin Thohari, Komisi Yudisial dan Reformasi Peradilan, Jakarta: Elsam, 2004, p. III, p. 30.

2 Soeparto, "Kedudukan dan Kewenangan Komisi Yudisial di Beberapa Negara Eropa (Irlandia, Perancis, dan Italia)", Syiar Hukum, Vol. 13, No. 1, 2014, p. 190.

Ibid., p. 191.

4 The People Consultative Assembly in the annual session 1 to 9 November 2000, stated that the purpose of amendments to the 1945 Constitution by adding an article on the establishment of a judicial commission (article 24B) is to strengthen judicial power. See Makhamah Konstitusi, Naskah Komprehensif Perubahan Undang-Undang Dasar Negara Republik Indonesia Tahun 1945 Latar Belakang, Proses, dan Hasil Pembahasan 1999-2002, VI Book, Revised Edition, Jakarta: Sekretaris Jenderal Makhamah Konstitusi Republik Indonesia, 2010, pp. 597-711. 
According to Mahfud MD, Background judicial reform (law reform) itself is based at least three things: ${ }^{5}$

"First the Mafia (precisely judicial corruption) involving judges and other law enforcer. Second; many regulations, including laws product, which is substantively considered contrary are higher, including the 1945 Constitution of the Republic of Indonesia (1945 Constitution), but no institution or mechanism effective for examine through judiciary (judicial review). Currently have only testing by legislative (legislative) and testing by executive (executive review) which is certainly very depend the President (executive heavy) underlying. Third, the vulnerability of the judges will be intervention by the powers of government because the laying of the judge under guidance of the government (for personnel administration and financial) and SC (for technical judicial). Even the judges are also vulnerable to the intervention of his own superiors so that in dealing with the case or will take the decision of the judges consult or ask for directions to his superiors.

The 1945 Constitution is not exclusively explain whether embracing personal independence or institutional independence or both. In this case, there are two opinions. First, independence judicial authority is institutionally, in a separate sense from executive and legislative. Second, personal freedom of the judges (personal independence) means there should be no influence the judge to examining and deciding cases.

Komisi Hukum Nasional or known as National Law Commission (NLC) believes have personal and institutional independent for when the personal independence, without supervision, abuse of power occurs. Lord Acton said, "Power tends to corrupt, and absolute power corrupts absolutely". ${ }^{6}$ Rogue judges often make this independence as a shield. They hide behind judicial independence. ${ }^{7}$ The judicial power independence is independent power and responsibility that are part of democracy pillars after a government that is open, accountable, and responsive. This can be realized with the support of a conducive and adequate from structural institutional, aspects substantive, cultural, good leadership, adequate welfare, and community participation. ${ }^{8}$

Law Number 22 of 2004 on Judicial Commission (Judicial Commission Law) states JC has important role efforts to establish an independent judicial authority through the nomination of justices and supervision of judges transparent and participatory to uphold honor and dignity. ${ }^{9}$ This paper is going to look at how to enhance roles of $\mathrm{JC}$ in the world.

Mahfud MD, "Judicial Power Post-Amendment 1945 the idea of Amendment 1945 a Recommendation", Komisi Hukum Nasional, 2008, p. 15.

6 Komisi Hukum Nasional, Gagasan Amandemen UUD 1945: Suatu Rekomendasi, Jakarta: Komisi Hukum Nasional RI, 2008, p. 5.

7 Mahfud MD, "Seminar on Role of Judicial Commission (JC) In the Judicial Mafia Eradication in the Era of Transition to Democracy", Komisi Yudisial Magazine, Vol. 6, June-July 2010, p. 17.

8 Muladi, "Peran Makhamah Konstitusi dalam Menjamin Hak Konstitusional Warga Negara pada Proses Demokratisasi di Indonesia", Jurnal Hukum dan Pembangunan, Vol. 39, No. 4, 2009, p. 437.

9 See Law Number 22 of 2004 on Judicial Commission (Judicial Commission Law). 


\section{B. General Overview of Judicial Commission in Several States}

The JC has adopted by at least 43 States in their constitution. ${ }^{10}$ of the 43 states, at least 20 of them have adopted $\mathrm{JC}$ with authority one of supervising or disciplining of the judges. ${ }^{11}$ Only two states that put JC beyond judicial power. They are Saint Lucia under the subtitles Appointment, etc., of the Magistrates, Registrars, and legal officers which is a sub-section of Chapter $\mathrm{VI}$; and the Solomon Islands that make it separate of Public Service Commission, one family with the, Police and Prisons Service Commission, etc., appointment to particular offices, and Appointment of Permanent Secretaries.

Due to limitations of space and time, in this paper the author only elaborates the practice of JC in several states by randomly took one state representing each continent where these states are, except Europe and Asia. America is represented by the United States of America. Europe includes the France and Netherlands, considering that Dutch legal system is similar to the Indonesian legal system. Asia is represented by Malaysia and Thailand. although they are members of the Association of Southeast Asian Nations (ASEAN), but they have different legal system with Indonesia. Africa is represented by South Africa that had already implemented JC. Australia is represented by New South Wales (NSW). The Indonesian JC is included to compare to these states.

\section{United States}

JC already exists in 50 states and District of Columbia. JC is an inseparable organ of judicial power and is not referred to by its constitution, but in the norm right in The Judicial Councils Reform and Judicial Conduct and Disability Act of 1980, which authorizes to the Judicial Conference of USA shape it as a disciplinary and Feasibility judges' institution. ${ }^{12}$

The task of JC in USA, among others, is putting a high standard and assessment of character the judges without any compromise. The Commission keeps strict watch public trust, and does a fair disposition on judges who violate the ethics and considered incapable. A task such as this is actually a challenge for the Indonesian Judicial Commission, which can strictly maintain public confidence.

In Wisconsin State, Supreme of Court formed JC in 1971. Seven years later existences of this commission be strengthened through laws became the legal basis in year 1978. Members of the commission consists of 9 (nine) people, including one trial judges, one roving judge and two lawyers, selected by the Supreme of Court and five from community members selected by the Governor with permission of Senate. JC in Wisconsin State has a managing director; with the requirement have an advocate permission. JC Wisconsin also has investigators and legal experts, which will provide an analysis of the investigation results and for the prosecution step.

Ahsin Thohari, Op.cit., p. 6.

11 Komisi Yudisial, Studi Perbandingan Komisi Yudisial di Beberapa Negara, Jakarta: Komisi Yudisial Republik Indonesia, 2008, p. xiii.

12 Ibid., p. 66. 
$\mathrm{JC}$ also have authority to examine all the documents the judge and see if the ethical guidelines implemented by a judge. In this state, JC has two tasks, namely to investigate and provide advice. In the event of a complaint on a judge, the commission will appoint a special team to conduct the preliminary investigation, which is an investigation. Result of the investigation brought to the commission meeting to be reexamined and then commissioners take decision a case feasible or not to be continued. The final verdict was taken after hearing testimony of the judge that be reported, with reference to the investigation result of the team. JC in Philadelphia State in charge of selecting and assessing candidates of the judge through criteria the legal ability, experience, temperament, administrative, integrity, and ability to explore the quality of law. The commission members are from various disciplines of law and ever conducted a legal practice.

JC Philadelphia, had the investigation division consisting of nine jurists. Nine division members observe on various matters relating to behavior the judges. In this case, as the investigator, writes a report on the case and recommend to the commission. The existence of this division is very important to maintain credibility of judges. The team members are elected from a variety of law enforcement profession, and they are on duty three years period and may be re-elected for one more time. The team is coordinated by a lawyer who fully understands legal aspects and judges.

\section{Netherlands}

JC who adopts monarchy was exist in year 2002, an independent institution. Known as Raad Voor de Rechtspraak (RvdR) or Netherland Council for Judiciary (NCJ). The name set in Judicial Act of 1827, Section 83A repealed on 01/01/2002 Part 6 . The agency was created with the purpose as independent institutions that address some of the problem in Dutch courts, including budget issues. Duties and authority of NCJ broadly comprise of the statutory tasks and other tasks. The statutory tasks include, judicial budget preparation; allocation of budget to the judiciary; operational support; support for the recruitment and selection procedures; improved quality and legal unity; general coaching duties for the new regulations. Non-Statutory Tasks) include, spokesman for justice and international cooperation

In general, the duties and functions RvdR consists of four groups. The first group includes the service to the public, judicial cooperation, personnel management, the judge selection policy, research policy, and advice to The Ministry of Justice, and policy of quality. The second group includes, accommodation and security, automation, administration, organization and administrative information. The third group includes the budget policy, budget distribution procedures, and justification of budget expenditures. The fourth group includes corrective authority for disciplinary, authority in process of nominating candidates for judge and promotions of judges. ${ }^{13}$

13 Sudut Hukum, "Komisi Yudisial di Belanda", https://www.suduthukum.com/2016/11/komisi-yudisial-dibelanda.html, accessed on March 2018. 


\section{French}

JC in France called the Conseil Superieur de la Magistrature (CSM) regulated in Title VIII of article 64 its Constitution. ${ }^{14}$ CSM, was existed 1946. JC became independent agency of the Government. Through amendment in 1958. CSM has undergone a number of changes in both the composition and organization. Tasks and competencies of CSM are primarily to provide input to appointment and discipline of judges. CSM is positioned as the balancer between president authority to appoint of judges and Minister of Justice appoint of Magistrates in running the judiciary. ${ }^{15}$

In the enforcing of discipline of judges, statute magistrate expressly provides restrictions that could result in action disciplinary being taken. Covers all measures that are qualified lead to failure in running the task management, requirements, accuracy, and degrading acts of honor, dignity and status as a judge.

In general, reports of non-disciplinary judge submitted to the CSM will be followed by disciplinary court proceedings. If this happens then implemented by Ministry of Justice with CSM member as a panel of judges without presence Chairman of CSM (President) and his vice (Minister of Justice). Besides these arrangements, disciplinary sanctions in statute de la magistrate also closely associated with prohibition for judges to criticize the government's policies or political propaganda during office.

In general, the duties and authority of JC France there are four groups. First groups, related to external affairs making the public service, judicial cooperation, personnel management, policy regarding the selection, research, provision of advice to Ministry of Justice, and the quality policy. The second group relates to the management and managerial namely accommodation and security, automation, organizational, administrative, and provision of information. The third group relates to budgetary procedures, procedures and the distribution of expenditure approval. The fourth group deals with corrective authority, nomination and appointment of judges, and education and training.

\section{Australia.}

This country does not have JC institution at the governmental level. JC in Australia are located in every federal state. In the NSW, for example, JC is originated from the confidence crisis to judiciary, which took place around September 1986, following a harsh debate between judiciary and government. The judicial officer law was published on November 8, 1986. ${ }^{16}$ Specifically addressed in section (3) and (4), the $\mathrm{JC}$ is a public agency with staffs that are independent of government influence and receive the budget independently of parliament.

The Constitution of France, amended on July, 26, 1993.

15 Wim Voermans, The Judicial Commission in several European countries, translated by Adi Nugroho and M. Zaki Hussein, Jakarta: Lembaga Kajian dan Advokasi untuk Independensi Peradilan (LeIP), 2002, pp. 72-73.

16 See Judicial Officers Act 1986 Number 100 of New South Wales, Australia. 
JC NSW function according Officer Act is, examine complaints against judicial officers; organize and right control, scheme for training and education for judicial officials; and assist courts in NSW consistency in criminal penalty. ${ }^{17}$ While the authority is examining claims about the abilities and behavior judicial authorities, to give a way to any person that conveys the complaint examined by an independent body. The commission determines complaint can be followed up by the standards prescribed. ${ }^{18} \mathrm{JC}$ NSW independent institution and consist of executive power. JC Chairman is ex-officio Supreme of Court Chairman. In NSW, JC as efficient institution with the task of managing administration, judicial education for judges, examining complaint to the judge give specific suggestions to the states, and help maintain the consistency of decisions. ${ }^{19}$

\section{Malaysia}

The government system in Malaysia recognizes The Judicial and Legal Service Commission (JLSC) set in article 138 of the Malaysian Constitution. ${ }^{20}$ However, it does not explicitly regulate authority. This institution has jurisdiction only covering all court employees. Its authority is to select and evaluate the appropriateness of prospective court employees, determine pensions, approve appointment of appointed court officials for other higher rank posts, promotions and mutations, and enforce disciplinary control over court employees. ${ }^{21}$ The membership of this institution consists of Chairman of Public Service Commission as Chairman, Attorney General, and one or more member appointed by King after consultation with Chairman of Supreme of Court.

\section{Thailand}

JC established to support the main functions of judicative as law enforcement and as a form of judicial function. Thailand itself was not familiar with term of judicial authorities. In Thailand, 2007 Thailand Constitution ${ }^{22}$, there is only the term Court set out in Chapter $X$ of the court, consisting of four (4) sections and 32 chapters ranging from Article 197 to Article 228. Under Chapter X, especially Article 200. It describes 4 (four) judiciary, namely (1) Constitutional Court, (2) Judicial Court (Judiciary), (3) Administrative Court (Judicial Administration), and (4) Military Court (Military Justice). Other than fourth set of these jurisdictions, judiciary chapter, ten (X) chapter, also regulates the other institutions as JC Institution, Court of Judicial Commission (CJC/General) Administrative of Court / JCAC (the Administrative Court

\footnotetext{
Sudut Hukum, "Komisi Yudisial di Australia”, https://www.suduthukum.com/2016/11/komisi-yudisial-diaustralia.html, accessed on March 2018.

18 Ibid.

19 Dian Rositawati, "KY Jilid III: Pekerjaan Rumah yang Belum Selesai", http://www.hukumonline.com/berita/ baca/It567b8b9c717f1/ky-jilid-iii--pekerjaan-rumah-yang-belum-selesai-broleh-dian-rositawati-, accessed on February 2018.

20 Article 138 (1) of the Constitution of Malaysia.

21 See Idul Rishan, Komisi Yudisial: Suatu Upaya Mewujudkan Wibawa Peradilan, Yogyakarta: Genta Press, 2013.

22 See Constitution of the Kingdom of Thailand 2007.
} 
Commission), regulated in section 2 (general), in particular Article 218 until 222, section (3) JCAC in particular Article 224 until Article 227 Thailand Constitution 2007.

Duties and authority of CJC under Article 220, namely, to approve appointment removal judges before proposed to the King; and gave approval for promotions, raises, administrative punishment to the judge. Medium duties and JCAC under Article 224 and 227, which in essence is the first, give approval on removal of an administrative judge before being considered by the King; second, the designation must be made not less than 1/3 number of judges Administrative Supreme Court and must approve by the Commissioner of administrative court as provided by law and by the Senate before being considered by the King; third, to give approval for promotions, raises, administrative punishment to the judge; and fourth even JC has the authority to approve appointment of Secretary General of Supreme of Court.

Both of JC has relationship with several state agencies in Thailand, such as executive and legislative. Forms of cooperation can be seen in process appointment and removal, including administrative judges. The process should not be done by the King as authority holders who represent executive if there is no referral from the two JC institutions. Therefore, the process can only be done if the two JC institutions are working together. Beside working with the executive, the two JC institutions also have relationship with judicative. The shape of the institute partnerships relations can be seen in promotion, salary increases, penalties against administrative court judges Relationships is governed by Article 220, 2007 (for JC Institute for Ordinary courts, and Article 224 for JC Administrative Court). Not only that, JC Administrative Court also granted authority to give consent to appointment of the Secretary General of Supreme of Court. Regulated arrangements concerning appointment, transfer, promotion, salary increases, and administrative punishment to the judge by the two agencies JC in Thailand. It is very obvious that building a harmonious relationship between JC, executive and judicative will benefit all institutions involved.

\section{South Africa}

JC named a Judicial Commission on the Court of Justice set in Section 174 of their constitution. The Commission's function is to provide advice to the President in appointment and dismissal chairperson and vice chairperson Constitutional Court and Supreme of Court and judges in all courts. Membership of the Committee is composed of several positions, namely Chairman of Supreme of Court as Chairman; Chairman of Constitutional Court; one judge as a result of selection; Cabinet member responsible in justice; two lawyers who are nominated by their organization and appointed by President; two prosecutors who are nominated by their organization and, one law lecturer chosen by the law faculty from universities in South Africa; seven from National Assembly in which three of them must be from opposition party; four persons who represent the province; and four persons who are elected by president after the approval by National Assembly. 
Article 165 Paragraph 2 of 1996 constitution asserts that judicial power is independent power only subject to constitution and applicable law, which should be enforced impartially without fear, favoritism, and prejudice. ${ }^{23}$ Then, Article 178 Paragraph (1) instruct for establishment (Judicial Service Commission / JSC). JSC is authorized, appointing judges and investigating complaints regarding judicial officials, providing input to the government on matters of judicial administration. ${ }^{24}$ According article 177 Paragraph (1) also set, judge may dismiss only if the JSC or Parliament concluded that the judge did not competence or commit a serious mistake. ${ }^{25}$ It was clear that South Africa put JC as an independent institution under the control of judicative.

\section{JC in Indonesia}

In Indonesia, existence of JC was initially intended to increase independence and accountability judicative authorities, since the adopted new system, "one roof system" that requires all judicial institutions both technically judicial or organization financially under judicative authorities Supreme of Court. ${ }^{26} \mathrm{JC}$ authorized to propose appointment of justices and uphold honor, dignity, and behavior of the judges. ${ }^{27}$ This based on idea that justices who settle on Supreme Court and judges are figures that are crucial in the struggle to uphold law and justice. Moreover, the supreme justices sit at highest level in the order of justice. As a state of law, a matter of honor, dignity and behavior all judges are very strategic to support reliable justice enforcement efforts as the realization concept Indonesia is a state based on rule of law. ${ }^{28}$

Based on Article 24B of the 1945 constitution, which is still valid, JC is a part of judicative power, but it is not assigned to conduct the technique of law enforcement (judicial engineering) or actor of judicial power like Supreme and constitutional Court (CC). JC is the supervisory agency of the workings judges in JC and CC. Consequently, JC is placed in judicial power chapter, that is chapter IX Section 24A, 1945 constitution. ${ }^{29}$ Therefore, JC is authorized to supervise entire execution of judges, including constitution judges. Nevertheless, unfortunately, this is not recognized which is to judge and decide on itself through Decree Number 005/PUUIV/2006 that Judge CC is not controlled by JC. ${ }^{30}$ Furthermore, Article 2 of Judicial

23 Jacob Tobing, "Komisi Yudisial", https://nasional.kompas.com/read/2015/07/29/16000011/Komisi.Yudisial, accessed on March 2018.

24 Ibid.

25 Ibid.

26 Prior to the reforms (the era of President Soeharto / New Order) is technically four judicial courts are under the Supreme Court. But in financial organizations under different ministries, the Ministry of Justice for umun judicial and administrative courts, the Department of Defense and TNI headquarters for the military court and the Ministry of Religion for religious courts.

27 Article 24B(1) of 1945 Constitution of the Republic of Indonesia (1945 Constitution).

28 A. Ahsin Thohari, Op.cit., p. 86.

29 Article 24(B) of 1945 Constitution.

30 This judgment comes from a judicial review by 31 Supreme Court judges who argued by the coming into effect of the Judicial Commission Law, the rights and authorities of the Supreme Court Justices were impaired, because, firstly, there is judge definition restrictions. definition set forth in Article 1 number 5 , that the judge includes all 
Commission Law states JC is a state institution which is independent and in the implementation of its authority free from interference or influence of other powers. The question is whether JC completely free and independent?

The notion free (Vrijheid) means that JC can perform all actions related to the duties and authority, not violating the provisions of the legislation in force. While independent (Zelfstandigheid) defined as controlling of character the judges which should not be influenced by anyone, including the executive, legislative and judicative and even from JC itself. Thus, what is meant by independent in my opinion is to organize themselves purely without any intervention or assistance from others. ${ }^{31}$ President Soekarno calls it "self-sufficient" -standing and strength by itself.

So, it can be inferred that the freedom of the judge is not defined literally, but limited freedom, which is regulated by the rules and code of ethics of the judge in carrying out their duties. In other words, the freedom of the judge is "limited freedom" in carrying out judicial engineering duties. While respecting of honor, dignity, discipline, ethics and behavior must be limited and supervised by an independent institution, which is responsible for that, namely JC.

The task and authority of JC is to propose appointment Supreme Court justices to the Parliament and supervise of honor, and dignity of judges. JC supervision performed does not include supervision behavior of judges in implementation of judicial technical task (to examine and decide). The supervision of authority has separate mechanism, that is appeal and cassation to supreme of Court as an institution of holders of power. However, in practice the judge's behavior often stems from a verdict which is considered beyond reasonable or contrary with sense of justice in the community. Many people report the behavior of judge to JC, often forcing JC to read the verdict and even call the judge to examine it, came from judge's decision.

judges, Supreme Court Justices and Constitutional Justices. Article 34(3) of the Judicial Power Law concerning the supervision of Judicial Commission covering Supreme judge and Judge. Second, Supervision of the judges set forth in the provisions of Article 20 regarding the duties of the Judicial Commission supervise the behavior of judges in order to maintain the dignity and honor of the judge. Article $22(1 \mathrm{e})$ regarding JC's recommendation on the results of judge behaviour examination submitted to SC and CC with copies to the President and Parliament, and Article 22(5) related to the obligation of the Supreme Court and / or the Constitutional Court to issue a determination in the form of coercion to the justice or judge to provide information or data requested by JC in the context of judicial supervision. The existence of the expansion of the definition of the judge caused the Supreme Court justices and judges were not independent, so request to the Court that the Supreme Court Justices did not become the object of supervision of JC. CC in its verdict stated that the extension of judge's limitation in Article 1(5) of the Constitutional Court Law is contradictory because it can spay the function of the Constitutional Court in deciding disputes between state institutions whose authorities are granted by the Constitution. In addition, JC is not involved in the selection and appointment of Constitutional Court Justices and the Constitution does not intend to authorize JC in supervising the conduct of Constitutional Justices. As a consequence, the articles of the JC Law which include Constitutional Justices are declared non-binding by the CC. Unlike the Supreme Court Justices. The CC has opinion that the Supreme Court justices within the limits of a judge that does not escape the supervision of JC. The Chief Justice is the judge, It is just the Supreme Judge is at the highest hierarchy of judges in the judiciary. Actually the supervision of JC of all judges at any level and any institution.

31 Ujang Bahar, "The Local Government Authority on Foreign Loans as an Alternative to the Fund Made Available from the Regional State Budget", Ph.D. Disertation, Universitas Padjadjaran, 2008, p. 164. 
Controversy arises because according to SC, this is an authority (judicial technique). As a result, the independence of which is owned by JC is not independent in the true sense. The institution is independent, but the individuals (the members) are not independent. In practice, judges allegedly infringing which degrading, behaviors, and honorary judges (unethical code of judges).

With regard to the authority of JC to appointment Supreme justices, JC has a very limited authority that only covers to propose appointment justices to the Parliament (Article 13(1) of Judicial Commission Law, which has refined by Law Number 18 of 2011 on the amendment to the Law Number 18 of 2011 on Judicial Commission). With a ratio of three to one (3: 1), it means that for one judge were vacant; the JC will submit three candidates to the House of Representative (Parliament) Furthermore, the Parliament who will choose one of them. In such a situation cannot be said the JC to be independent in determining the nominees. Precisely parliament was free and independent. While JC just be a subordinate of the Parliament. In other languages that JC just become second-class state institutions (The second Institution) to both Parliament and Supreme Court. This is all as result of formation of JC which half-hearted or hasty, in addition any political interests. JC existence less placed appropriately in the Indonesian constitutional structure. Placement in institutional constitution theoretically not automatically categorized as a constitutional institution, the tools completeness of state as organizer of state organizations, acting for and on behalf of the country. ${ }^{32}$

More indicative of the problems described above, strengthening the role of JC can still be done, so that JC not only a second-class state institution. However, being a state institution with the same degree and position with other constitutional institutions in the 1945 , JC presence rightly to develop modern Indonesian based on rule of law to take over some functions of their parent institutions of SC.

Regarding the strengthening of authority of $\mathrm{JC}$ in process of appointing nominees of supreme judge, if it follows the pattern of principle separation of power with checks and balances, Parliament unnecessary involved in the recruitment process. This is the fully jurisdiction of JC. Parliament functions as the controller of the process. The members of JC are not selected by the Parliament. It's imperative JC recruitment and determination of the amount needed (no need to 3:1), and then submitted to the President for approval. Logically "president who appoints JC member by the proposal / approval of Parliament, President should not intervene authority JC. This means that if President does not trust the professionalism of members JC to recruit nominees of supreme judge, from the beginning the President must reject membercandidates of JC proposed by Parliament. ${ }^{33}$ In my opinion the authority raised the judge candidate not limited just to the nominees of supreme judge, but judges for

\footnotetext{
Bagir Manan, "Hubungan Ketatanegaraan MA dan MK dengan Komisi Yudisial (suatu pertanyaan)", paper presented at a discussion organized by the Golkar Party faction, March 9, 2006, p. 43.

33 Yuliandri, "Independence and Accountability of Judicial Power Post Amendment to the 1945 Constitution", in Komisi Hukum Nasional, Gagasan Amandemen UUD 1945: Suatu Rekomendasi, Op.cit., p. 66.
} 
all levels under SC, included other special magistrate judges.

Regarding the JC authority to supervise the behavior of the judges, it should be conducted in a spirit of keeping the balance and accountability for implementing judicial power. Therefore, oversight conducted by JC is supervision for all judges, not only the judges who are in SC but also, whom are in Constitutional Court, and even other special judges. ${ }^{34}$

\section{Conclusion}

There are many different in practice of JC institutions, depending on government system, historical background, and states interests concerned. However, each country believes the JC presence a very important role for their statehood life. Therefore, each country should develop the role of JC institutions by taking positive things on JC practice. This can be done by collaborating among institutions; complete each other, discuss and exchange opinions with one another as well as building cooperation in the forum of world organization of JC, as for instance at the International BAR for attorneys, tailored made for the goals and interests of each state.

Especially for Indonesia, beside international cooperation, increasing role of $\mathrm{JC}$ in Indonesia still be improved through institutional reform, with strengthen and extend role and authority. Steps can be developed through, first strengthen the JC authority to supervise judge's behavior. In the monitoring of behavior, upholding dignity, dignity and honor of judges should read as keeping spirit of balance and accountability for implementing judicial power. Therefore, oversight conducted by JC is a supervision for all judges naturally, including the constitutional other special judges. Second, by amendments of 1945 constitution, particularly those governing of JC namely Article 24B, 1945 Constitution, by adding the words "including constitutional judges" in Article 24B(1) of 1945, Constitution, so that Article 24B(1) reads as "Independent judicial commission is authorized to propose appointment and other authorities to uphold honor, dignity and behavior of judges. Including constitution judges". ${ }^{35}$ Thus no reason for constitutional judges to refuse to be supervised by JC. JC will really be a credible state institution to maintain, uphold honor, dignity, and behavior of judges. Third, expand the JC authority to appoint the judge, not limited only to nominee a supreme judge, but judges at all level under Supreme Court, including special judges. So that it will implement the idea of "one gate system". Even JC should be given duty to evaluate the performance of supreme justices after serving for five years or more as Supreme Court, whether meets the

34 A step forward has been taken by JC. Tax judge officially became the object of scrutiny JC with the signing of the Memorandum of Understanding (MoU) the three institutions on 16 July 2010. The MoU was briefly the contents governing tax judges guidance, supervision and monitoring reporting State officials wealth tax court judge. The three institutions agreed to establish the Tax Court Reform Team. Minister of Finance had previously been anticipating it through issuing Minister of Finance Decree Number 191/KMK.01/2010 on the Tax Reform Team.

35 See Article 24B of 1945 Constitution. Now chime Independent judicial commission is authorized to propose the appointment of justices and have other authorities in order to preserve and uphold the honor, dignity, and the behavior of judges the honor, dignity, and the behavior of judges. 
criteria or standards of competence as chief judges or not. Especially for judges that originated from non-career. So, becoming a supreme justice will not be assumed as a life time position. If one is not eligible or meet the competency standards, it can be proposed to the president for a dismissal.

The position and status of JC are different in each country. Some states make it as an independent institution under the King, part of judicial power, be a liaison between government power (Executive power) and judicative power, executive or even under Ministry of Justice. To be sure, all of them making JC as supporting institutions of judicial authority to provide a judicial independence guarantee. However, in its implementation there are several models. The first model is generally in north Europe. The model focuses on making technical policy areas of justice. The first function covers how to streamline budgets justice, making Standard Operational Procedure (SOP) policies regarding public relationship. The second function is managerial functions performed to the judiciary, which includes housing for judges, courtrooms, information. Other models (particularly in southern Europe) are more focused to authority, careers, recruitment of judges, permanent education, periodic training, rotation, mutation, and promotion of judges, and enforcement of discipline. ${ }^{36}$

Although there are states that put JC under judicative but none of the states which authorizes to JC to conduct an audit of the decision (verdict) in supervise, guard of honor, dignity, ethics of judge's verdict. The grounds are judicial techniques and already have separate mechanism appeal or cassation, even though in the reality the judge's behavior often stems from a verdict, which is considered beyond reasonable in the community, especially for decision nuanced of politically or a decision against political figures or other society figures. Therefore, it is proportional if all the states give authority to JC to conduct a judicial audit against the judge's decision, especially from the sociological and psychological discharge the verdict. So that the JC role to uphold justice in a society will be useful.

\section{References}

\section{Books}

Ahsin Thohari, Komisi Yudisial dan Reformasi Peradilan, Elsam, Jakarta, 2004.

Idul Rishan, Komisi Yudisial: Suatu Upaya Mewujudkan Wibawa Peradilan, Genta Press, Yogyakarta, 2013.

Komisi Hukum Nasional, Gagasan Amandemen UUD 1945: Suatu Rekomendasi, Komisi Hukum Nasional RI, Jakarta, 2008.

36 Currently Indonesian JC prefer this model because JC did not take care of the judicial budget. Article 24B(1) of 1945 Constitution stated the Judicial Commission is independent authorized to propose the appointment of justices and have other authorities in order to preserve and uphold the honor, dignity, and behavior of judges .. Article 13 of Judicial Commission Law states the Judicial Commission has the authority to propose the appointment of Chief Justice to the Parliament; and uphold the honor and dignity and maintain the behavior of judges. 
Komisi Yudisial, Studi Perbandingan Komisi Yudisial di Beberapa Negara, Komisi Yudisial Republik Indonesia, Jakarta, 2008.

Makhamah Konstitusi, Naskah Komprehensif Perubahan Undang-Undang Dasar Negara Republik Indonesia Tahun 1945 Latar Belakang, Proses, dan Hasil Pembahasan 1999-2002, VI Book, Revised Edition, Sekretaris Jenderal Makhamah Konstitusi Republik Indonesia, Jakarta, 2010.

Voermans, Wim, The Judicial Commission in several European countries, translated by Adi Nugroho and M. Zaki Hussein, Lembaga Kajian dan Advokasi untuk Independensi Peradilan (LeIP), Jakarta, 2002.

\section{Other Documents}

Bagir Manan, "Hubungan Ketatanegaraan MA dan MK dengan Komisi Yudisial (suatu pertanyaan)", paper presented at a discussion organized by the Golkar Party faction, March 9, 2006.

Dian Rositawati, "KY Jilid III: Pekerjaan Rumah yang Belum Selesai", http://www. hukumonline.com/berita/baca/It567b8b9c717f1/ky-jilid-iii--pekerjaan-rumahyang-belum-selesai-broleh--dian-rositawati-, accessed on February 2018.

Jacob Tobing, "Komisi Yudisial", https://nasional.kompas.com/ $\mathrm{read} / 2015 / 07 / 29 / 16000011 / K o m i s i . Y u d i s i a l$, accessed on March 2018.

Mahfud MD, "Judicial Power Post-Amendment 1945 the idea of Amendment 1945 a Recommendation", Komisi Hukum Nasional, 2008.

------------, "Seminar on Role of Judicial Commission (JC) In the Judicial Mafia Eradication in the Era of Transition to Democracy", Komisi Yudisial Magazine, Vol. 6, June-July 2010.

Muladi, "Peran Makhamah Konstitusi dalam Menjamin Hak Konstitusional Warga Negara pada Proses Demokratisasi di Indonesia", Jurnal Hukum dan Pembangunan, Vol. 39, No. 4, 2009.

Soeparto, "Kedudukan dan Kewenangan Komisi Yudisial di Beberapa Negara Eropa (Irlandia, Perancis, dan Italia)", Syiar Hukum, Vol. 13, No. 1, 2014.

Sudut Hukum, "Komisi Yudisial di Australia", https://www.suduthukum. com/2016/11/komisi-yudisial-di-australia.html, accessed on March 2018. , "KomisiYudisial diBelanda", https://www.suduthukum.com/2016/11/ komisi-yudisial-di-belanda.html, accessed on March 2018.

Ujang Bahar, "The Local Government Authority on Foreign Loans as an Alternative to the Fund Made Available from the Regional State Budget", Ph.D. Disertation, Universitas Padjadjaran, 2008.

\section{Legal Documents}

1945 Constitution of Republic of Indonesia.

Law Number 24 of 2003 on Constitutional Court.

Law Number 4 of 2004 on Judicial Power. 
Law Number 5 of 2004 on the Amendment to the Law Number 14 of 1985 on Supreme Court. Law Number 22 of 2004 on Judicial Commission.

Law Number 18 of 2011 on the Amandment to the Law Number 22 of 2004 on Judicial Commission.

Indonesian Constitutional Court Decree Number 005/PUU-IV/2006.

Minister of Finance Decree Number 191/KMK.01/2010 on the Tax Reform Team.

Constitution of Malaysia 1957.

Constitution of France, amended on July, 26, 1993.

Constitution of the Kingdom of Thailand 2007.

Judicial Officers Act 1986 Number 100 of New South Wales, Australia. 